\title{
Ore mineralogy and mineral chemistry of quartz-chalcopyrite veins from the Krusha ore occurrence, Western Srednogorie, Bulgaria
}

\section{Рудна минералогия и химизъм на минералите от кварц-халкопиритови жили от рудопроявление Круша, Западно Средногорие, България}

\section{Ralica Sabeva \\ Ралица Събева}

Sofia University St. Kliment Ohridski, Faculty of Geology and Geography, 1504 Sofia, Bulgaria;

E-mail: rsabeva@gea.uni-sofia.bg

\begin{abstract}
The Krusha ore occurrence is located in the western part of the Srednogorie zone. The quartz-chalcopyrite veins are hosted by altered basaltic andesites. The styles of alteration are propylitic, sericitic, argillic and advanced argillic. The ore veins consist mainly of chalcopyrite, quartz and carbonates. Native copper is observed as single grains. Chalcopyrite is with high contents of Se. Au is up to $3.13 \mathrm{ppm}$ with average contents of $1.43 \mathrm{ppm}$.
\end{abstract}

Keywords: Krusha, Western Srednogorie, ore mineralogy, LA-ICP-MS of chalcopyrite.

\section{Introduction}

The Krusha ore occurrence is located in the area of the Krusha village, $2 \mathrm{~km} \mathrm{~W}$ of the border with Serbia. It is situated in the western part of the Srednogorie zone in Bulgaria, which in regional aspect belongs to the Late Cretaceous Apuseni-BanatTimok-Srednogorie magmatic and metallogenic belt (Popov et al., 2002), hosting $\mathrm{Cu}$ - and Au-rich porphyry and epithermal deposits.

Previous works on the Krusha ore occurrence present data of the host rocks and hydrothermal alteration (Velinov, 1973; Velinov et al., 2007). The aim of this study is to add new data about the ore minerals and their chemistry which will help to constrain the ore-forming system and the significance of the ore potential of the prospect.

\section{Sampling and analytical techniques}

The samples are collected from quartz-chalcopyrite veins, hosted by propylitic alteration. Polished sections were prepared to determine the paragenetic relationships of the ore minerals.

$\mathrm{X}$-ray powder diffraction (XRD) analyses were performed on a TUR M62 diffractometer using fil- tered $\mathrm{Co}-\mathrm{K} \alpha$ radiation in the $2 \theta$ range $4-80^{\circ}$, step size $1.5^{\circ}$ at Sofia University St. Kliment Ohridski, Sofia, Bulgaria.

Scanning Electron Microscopy and Energy Dispersive Spectroscopy (SEM-EDS) were done on carbon-coated polished sections with a SEM JEOL JSM 6610LV equipped with an EDS detector at the University of Belgrade, Serbia. Standards used were $\mathrm{CuFeS}_{2}(\mathrm{Cu}, \mathrm{Fe}, \mathrm{S})$, metallic $\mathrm{Mn}(\mathrm{Mn}), \mathrm{ZnS}$ (Zn), InAs (As), metallic Se (Se), CdS (Cd), metallic $\mathrm{Ag}(\mathrm{Ag}), \mathrm{Ag}_{2} \mathrm{Te}(\mathrm{Ag}, \mathrm{Te}), \mathrm{InSb}(\mathrm{Sb})$, metallic $\mathrm{Co}$ (Co), metallic Ni (Ni), metallic Bi (Bi), $\mathrm{PbS}(\mathrm{Pb})$, metallic $\mathrm{Au}(\mathrm{Au})$.

Trace element concentrations in pyrite were measured by LA-ICP-MS on polished sections at the Geological Institute (Bulgarian Academy of Sciences). A total of 28 analyses were performed on PerkinElmer ELAN DRC-e ICP-MS equipped with a New Wave UP193-FX excimer laser ablation system. NIST SRM 610 glass and MASS 1 was used as external standard and stoichiometric Fe as internal. The laser system was operated at constant $10 \mathrm{~Hz}$ pulse rate; laser energy was $10.10 \mathrm{~J} / \mathrm{cm}^{2}$ on SRM 610 glass and $1.90-3.06 \mathrm{~J} / \mathrm{cm}^{2}$ on sample. Spot size was $50 \mu \mathrm{m}$ in diameter. Acquisition dwell time for all masses was 
set to $0.01 \mathrm{~s}$. Data reduction was undertaken using SILLS ver. 1.1.0 software (Guillong et al., 2008).

\section{Geological background}

The Krusha ore occurrence is located in Western Srednogorie, Burelska ore zone according to metallogenic division of Bairaktarov (1989). The main rock types presented in the area of the occurrence are Upper Cretaceous marls, sandstones, limestones, andesites and andesite lava breccias (Velinov, 1973). Volcanic rocks are products of the Burel paleovolcano and belong to the Lower volcanogenic-sedimentary unit (Bairaktarov,1989; Dabovski et al., 2009).

Several alteration zones are established. They are hosted mainly by andesites and associate with faults $\left(290-325^{\circ}\right)$. The styles of alteration are propylitic, sericitic, argillic and advanced argillic. Propylitic alteration is extensive and surrounds the other types of alteration. The mineral alteration assemblages are epidote-chlorite and chloritecarbonate. Sericite alteration consists of quartz, sericite and pyrite as chlorite and carbonate appear at the transition with propylites. Argillic alteration consists mainly of kaolinite and metahalloysite. Advanced argillic alteration is represented as vein-shaped bodies, up to $100 \mathrm{~m}$ long with average thickness $10-12 \mathrm{~cm}$. The alteration consists of quartz, alunite, kaolinite, illite, pyrite and rare rutile. Au up to $0.14 \mathrm{~g} / \mathrm{t}$ is established in altered samples (Velinov et al, 2007).

\section{Ore mineralogy and mineral chemistry}

Ore mineralization occurs in quartz-chalcopyrite veins, several centimeters thick. The veins are hosted by the propylitic alteration. Mineral composition of the propylites is represented by chlorite, carbonates, rare epidote, sericite and zeolites in amygdales. The chlorite-carbonate alteration assemblage is common while the epidote-chlorite is rare. Relicts of primary amphibole, pyroxene, plagioclase and rare biotite phenocrysts can be often observed.

The ore veins consist mainly of chalcopyrite and gangue minerals, represented by quartz and carbonates.

Chalcopyrite occurs as anhedral aggregates in nests or build the central parts of the veins. The size is predominantly up to $50 \mu \mathrm{m}$, rarely up to $1-2 \mathrm{~mm}$. Chalcopyrite is often replaced by supergene copper sulfides, mainly by malachite which forms rims and net-mesh-like microtextures. SEM-EDS analyses show chemical composition close to stoichiometry.

The LA-ICP-MS analyses of chalcopyrite reveal the presence of $\mathrm{Se}, \mathrm{Pb}, \mathrm{Te}, \mathrm{Mn}, \mathrm{Ag}, \mathrm{Zn}$ and rare $\mathrm{Cd}$, $\mathrm{Bi}, \mathrm{Co}, \mathrm{Au}$. Selenium is the most common and with highest concentration (from 89.13 to $2289 \mathrm{ppm}$, average $1087.76 \mathrm{ppm}(0.11 \%)$. Chalcopyrite often hosts Se due to the possibility of formation of solid solution with eskebornite $\left(\mathrm{CuFeSe}_{2}\right)$ above $390{ }^{\circ} \mathrm{C}$ (Bethke, Barton, 1971). The contents of Se in the samples from the Krusha ore occurrence significantly exceed the maximum contents, reported for chalcopyrite from different genetic types of deposits (78 ppm in Toroiaga epithermal deposit, $136 \mathrm{ppm}$ in Baita Bihor skarn deposit, 313 ppm in Elatsite porphyry deposit, 849 ppm in Sulitjelma VMS deposit (George et al., 2018)). Selenium in chalcopyrite with contents above $0.002 \%$ is economically important (Butterman, Brown, 2004). Pb concentrations (from 0.32 to $597.76 \mathrm{ppm}$, average $107.76 \mathrm{ppm}$ ) are probably the result of the presence of micro-inclusions of $\mathrm{Pb}$-bearing phases although such inclusions are not observed in the ore samples. Te contents are up to $86.99 \mathrm{ppm}$ (average $37.46 \mathrm{ppm}$ ). Chalcopyrite is a poor host for this element and its presence is due to isovalent substitution for sulfur in the lattice (George et al., 2018). Manganese (from 28.20 to $44.41 \mathrm{ppm}$, average $31.66 \mathrm{ppm}$ ), $\mathrm{Ag}$ (from 0.28 to $99.88 \mathrm{ppm}$, average $24.44 \mathrm{ppm}$ ) and $\mathrm{Zn}$ (up to $33.33 \mathrm{ppm}$, average 19.09) were detected and probably are inclusion-related. Cadmium, $\mathrm{Bi}$, and Co are with lower concentrations in chalcopyrite. Gold is up to $3.13 \mathrm{ppm}$ with average contents of $1.43 \mathrm{ppm}$. The irregular profiles of the depth spectra suggest that the gold is represented as microinclusions.

Single grains of native copper up to $15 \mu \mathrm{m}$ are observed among gangue minerals. SEM-EDS analyses show $\mathrm{Cu}$ contents in the range of 93.92$93.95 \mathrm{wt} \%$, but alloy elements are not determined.

Supergene alteration has affected the sulfides. The supergene minerals are proven also by XRD and represented by secondary copper-bearing phases as malachite, enclosing chalcopyrite and iron oxide-hydroxides as hematite and goethite, which occur as nests and veinlets from a few $\mathrm{mm}$ to $1-1.5 \mathrm{~cm}$ thick.

\section{Conclusions}

The Krusha ore occurrence is still poorly understood in Srednogorie zone. The alteration styles and ore mineralization, reported in this study assume the presence of a probable epithermal system and related copper and gold concentrations. The new data on the ore mineralogy and mineral chemistry confirm the potential of the area, but more geological and analytical work is needed.

Acknowledgments: This work was financially supported by the DM 04/2 grant from 13.12.2016 of the National Science Fund Bulgaria. 


\section{References}

Bairaktarov, I. 1989. Upper Cretaceous Metallogeny of Western Srednogorie and Plana Mountain. PhD Thesis, Sofia, Research Institute for Mineral Resources, 197 p. (in Bulgarian).

Bethke, P. M., P. B. Barton. 1971. Distribution of some minor elements between coexisting sulphide minerals. Econom. Geol., 66, 140-163; https://doi.org/10.2113/ gsecongeo.66.1.140.

Butterman, W. C., R. D. Brown. 2004. Mineral Commodity Profiles: Selenium. Open-file report 2003-18, USGS, 20 p.; http://pubs.er.usgs.gov/publication/ofr0318.

Dabovski, C., B. Kamenov, D. Sinnyovsky, E. Vasilev, E. Dimitrova, I. Bairaktarov. 2009. Upper Cretaceous geology. - In: Zagorchev, I., C. Dabovski, T. Nikolov (Eds.). Mesozoic Geology of Bulgaria. Sofia, Prof. Marin Drinov Academic Publishing House, 305-611.

George, L. L., N. J. Cook, B. B. P. Crowe, C. L. Ciobanu. 2018. Trace elements in hydrothermal chalcopyrite. -
Mineral. Mag., 82, 1, 59-88; https://doi.org/10.1180/minmag.2017.081.021.

Guillong, M., D. L. Meier, M. M. Allan, C. A. Heinrich, B. W. D. Yardley. 2008. Appendix A6: SILLS: A MATLAB-based program for the reduction of laser ablation ICP-MS data of homogeneous materials and inclusions. - In: Sylvester, P. (Ed.). Laser Ablation ICP-MS in the Earth Sciences: Current Practices and Outstanding Issues. Mineralogical Association of Canada Short Course 40, Vancouver, B. C., 328-333.

Popov, P., T. Berza, A. Grubic, I. Dimitru. 2002. Late Cretaceous Apuseni-Banat-Timok-Srednogorie (ABTS) magmatic and metallogenic Belt in the Carpathian-Balkan Orogen. - Geologica Balc., 32, 2-4, 145-163.

Velinov, I. 1973. Mineralogical-petrological Analysis of Hydrothermally Altered Upper Cretaceous Volcanics from the Western Part of the Srednogorie Zone. D. Sc. Thesis, Abstract, $29 \mathrm{p}$.

Velinov, I., A. Kunov, N. Velinova. 2007. The Metasomatic Secondary Quartzite Formation in Bulgaria. Sofia, Prof. Marin Drinov Academic Publishing House, 198 p. 